\title{
Homocystinuria due to Cystathionine Synthase
}

\author{
Deficiency: the Effect of Pyridoxine
}

\author{
S. Harvey Mudd, William A. Edwards, Peter M. Loeb, Michael S. Brown, and \\ LEONARD LASTER
}

From the Section on Alkaloid Biosynthesis, Laboratory of General and Comparative Biochemistry, National Institute of Mental Health, and the Digestive and Hereditary Diseases Branch, National Institute of Arthritis and Metabolic Diseases, Bethesda, Maryland 20014

A B S T R A C T We investigated the effect of pyridoxine administration in three patients with homocystinuria due to cystathionine synthase deficiency. The drug decreased the plasma concentration and urinary excretion of methionine and homocystine and the urinary excretion of homolanthionine and the homocysteine-cysteine mixed disulfide. Urinary cystine rose somewhat. Oral methionine tolerance tests before and during the patients' response to pyridoxine indicated that during response they remained deficient in their capacity to convert the sulfur of methionine to inorganic sulfate, although this capacity increased somewhat. During pyridoxine response only, the methionine loads caused increased homocystinuria. There was no indication that pyridoxine stimulated an alternate pathway of metabolism. The values for specific activity of cystathionine synthase in liver biopsy specimens from two patients in pyridoxine response were 3 and $4 \%$ of the mean control value. When these patients were not receiving pyridoxine, comparable values were 2 and $1 \%$, respectively. The hepatic enzyme activity of the mutant patients was similar to normal enzyme activity with respect to trypsin activation, heat inactivation, and stabilization by pyridoxal phosphate. Approximate estimates were made of the relation between total body capacity to metabolize methionine and hepatic cystathionine synthase activity. These estimates suggested that because of the large normal reserve capacity of cystathionine synthase, a few per cent residual activity is sufficient to metabolize the normal dietary load of methionine. Thus, small increases in residual capacity may be of major physiological importance. However, many liver biopsies would be required to establish unequivocally that such changes were due to the administration of a particular therapeutic agent rather than to biological variation. All the

Received for publication 16 March 1970 and in revised form 18 May 1970. data in the present study are consistent with the interpretation that pyridoxine does act by causing an increase in residual cystathionine synthase activity.

\section{INTRODUCTION}

The syndrome in man due to deficient activity of the enzyme cystathionine synthase (which catalyzes step 4 of the pathway shown in Fig. 1) is now well known (1, 2 ; for a recent review see reference 3 ). The enzyme deficiency, which has been demonstrated in liver (4-9), brain (10), and fibroblasts grown in tissue culture from skin specimens of affected patients (11), is characterized chemically by abnormal elevations of homocystine and methionine in plasma and urine. As first reported by Barber and Spaeth (12), the administration of pyridoxine to patients with this disease is, in some cases, followed by a reduction in the daily urinary excretion of homocystine and by a fall in the concentration of homocystine in blood plasma $(3,6,7,12-16)$. An understanding of the mechanism whereby pyridoxine exerts this effect would be not only of theoretical interest but would also aid in assessment of the therapeutic potential of pyridoxine. For these reasons, the present investigation of the mechanism underlying the pyridoxine responsiveness was undertaken.

\section{METHODS}

Clinical information. Patients K. B., J. H., T. K., and D. F. are homocystinuric. Each has been shown to be cystathionine synthase deficient by assay of extracts of liver $(5,10)$ or fibroblasts grown in tissue culture from skin biopsies. ${ }^{1}$ The normal volunteers were a $21 \mathrm{yr}$ old female, V. P., and a 22 yr old male, D. G. They were each evaluated by a medical history, physical examination, and laboratory tests, and they were found to be in excellent health.

${ }^{1}$ Uhlendorf, B. W., and S. H. Mudd. Unpublished observations. 


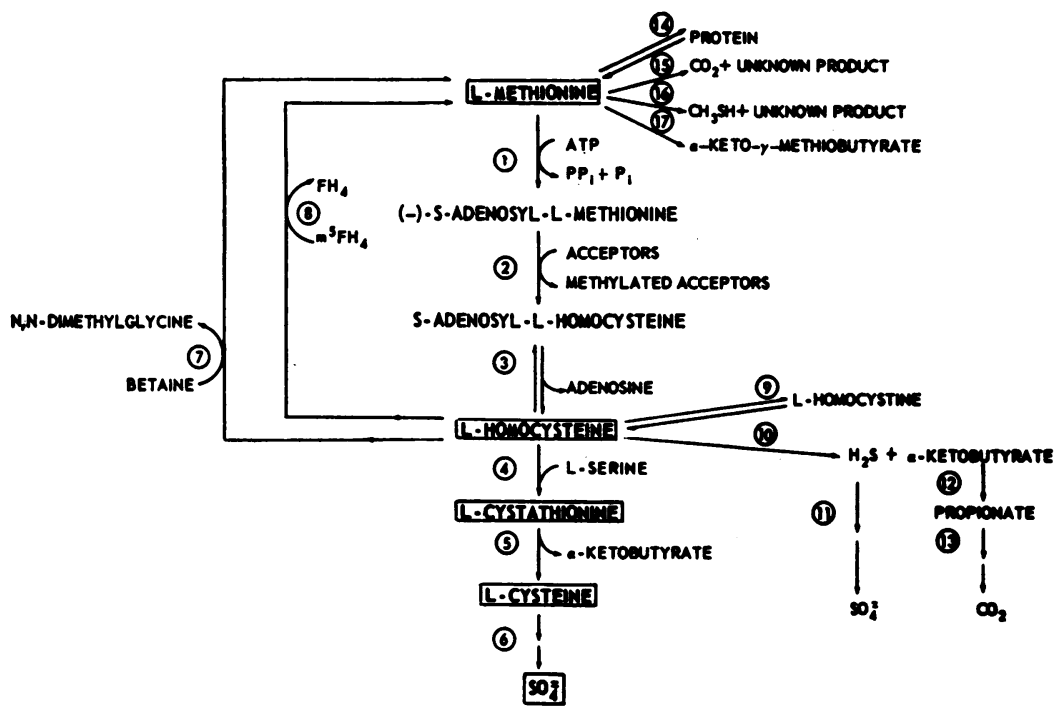

Figure 1 Current concepts of methionine metabolism in mammalian tissues. $\mathrm{P}_{1}$ and $\mathrm{PP}_{1}$ are inorganic phosphate and pyrophosphate. $\mathrm{FH}_{4}$ is tetrahydrofolic acid and $\mathrm{m}^{5} \mathrm{FH}_{4}$ is $\mathrm{N}^{5}$-methyltetrahydrofolic acid.

During the study each subject received a constant diet, the methionine and cystine content of which was estimated by use of published tables (17). The food was prepared and served under the supervision of a dietitian trained in techniques of metabolic balance studies. Each subject's body weight remained essentially unchanged during the study. 24-hr urine collections were started and ended at 9 a.m. Urine specimens were refrigerated immediately after passage and preserved with toluene. The specimens were pooled and frozen at the end of each $24 \mathrm{hr}$ collection period. Blood samples for determination of amino acids were drawn in the morning with the patient in the fasted state. L-Methionine was made up in gelatin capsules, each containing $0.25 \mathrm{~g}$ of amino acid, and administered orally at a dose of 0.5 mmoles/kg body weight. The subject was fasted from 10:00 p.m. the previous night. The amino acid was fed at 9:15 a.m., and breakfast was given at 10:00 a.m.

Materials and methods. Blood drawn for amino acid analysis was added to heparin. Plasma was separated immediately by centrifugation, and proteins were precipitated by addition of $2.5 \mathrm{ml}$ of $3 \%$ sulfosalicylic acid for each $1 \mathrm{ml}$ of plasma. The supernatant solution was stored frozen. Amino acids were determined with an automatic amino acid analyzer by use of either the buffer system of Spackman, Stein, and Moore (system A) (18), or a four-buffer gradient system described by Crawhall, Thompson, and Bradley (system B) (19). Each sulfur amino acid was identified in both solvent systems by cochromatography with authentic material and, where appropriate, by a distinctive ratio of absorptions of the ninhydrin color at 440 and $570 \mathrm{~m} \mu$.

Urinary content of inorganic sulfate was determined according to Fiske's modification of the method of Rosenheim and Drumond (20). The procedure was rigorously standardized by use of several modifications, and all determinations were performed in duplicate. ${ }^{2}$

${ }^{2}$ A detailed description of the method used is available in photocopies $(\$ 5.00)$ or microfiche $(\$ 2.00)$ and may be obtained by requesting No. 01015 from the National Auxiliary
The keto-acid analogue of methionine, $\alpha$-keto- $\gamma$-methylthiobutyrate, was prepared by a modification of the procedure of Meister (21) using L-methionine $-{ }^{14} \mathrm{CH}_{3}$ as starting material. ${ }^{2}$ The keto analogue was converted to the 2,4-dinitrophenylhydrazone derivative which was characterized by paper chromatography with several solvent systems. ${ }^{2}$ Keto acids in urine were converted to 2,4-dinitrophenylhydrazones as described (22). After partition between chloroform and $1 \mathrm{~N}$ ammonia, the ammoniacal extracts were used for paper chromatography (22).

Cystathionine synthase, cystathionase, and protein concentration were assayed as described (23). Cystathionine synthase activity was measured by homocysteine- and enzyme-dependent incorporation of serine- ${ }^{14} \mathrm{C}$ into a compound which was identified by column and paper chromatography as cystathionine ${ }^{14} \mathrm{C}$. After oxidation with $\mathrm{H}_{2} \mathrm{O}_{2}$, the reaction product had chromatographic properties identical with those of the oxidation product formed from authentic cystathionine (23). A unit of cystathionine synthase is the amount which catalyzes the formation of $1 \mathrm{~m} \mu$ mole of cystathionine per 135 min under the standard conditions. Specimens for enzyme assay were obtained from the patients by percutaneous needle biopsy of the liver. Twice recrystallized bovine pancreatic trypsin and crystalline pancreatic trypsin inhibitor were obtained from Worthington Biochemical Corp., Freehold, N. J. Pyridoxal phosphate (Calbiochem, Los Angeles, Calif.) solutions were neutralized and stored as described. ${ }^{3}$

\section{RESULTS}

The response to pyridoxine. Each patient with cystathionine synthase deficiency was given a constant diet containing approximately the same amount of

Publications Service of the A.S.I.S.-CCM Information Corp., 909 Third Ave., New York 10022.

s Giovanelli, J., L. D. Owens, and S. H. Mudd. Manuscript in preparation. 


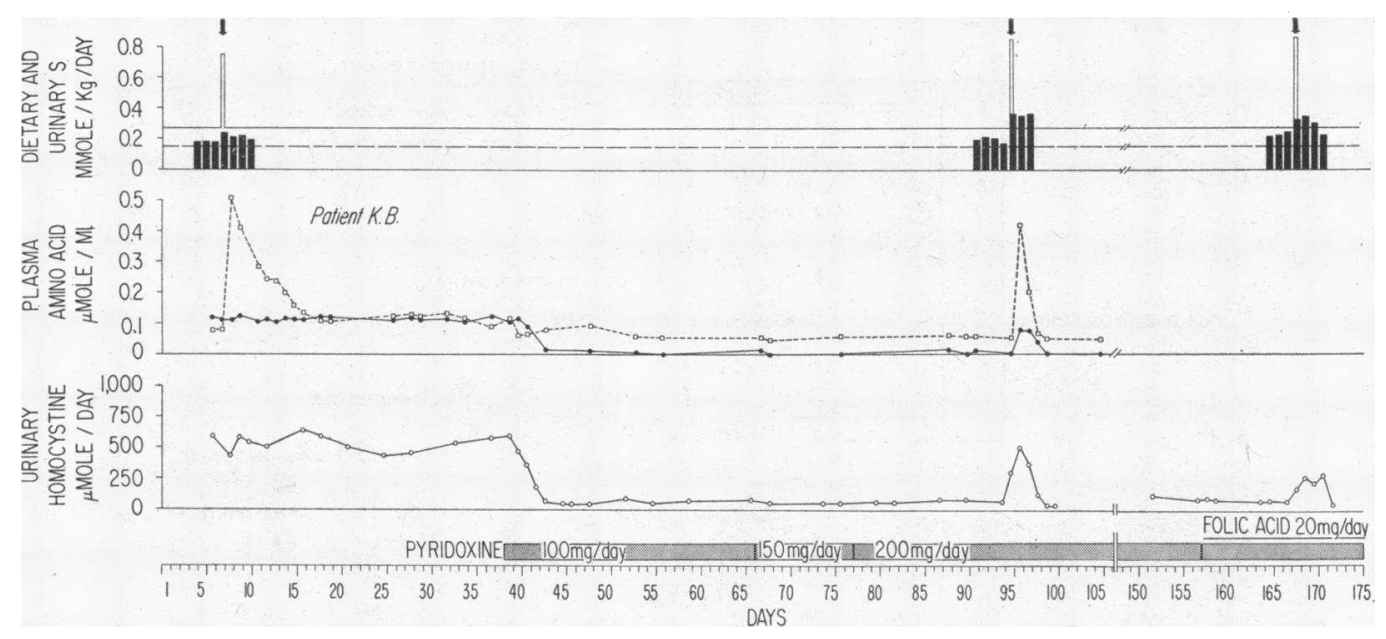

FIgURE 2 Effect of pyridoxine and of L-methionine administration in cystathionine synthasedeficient patient, K. B. Daily dietary intake and urinary excretion of sulfur (S) are shown at the top. Intake of cystine is represented by the dashed line; intake of methionine (as an increment over the cystine intake), by the solid line. Urinary inorganic sulfate is represented by the solid rectangles. Supplementary oral methionine doses are indicated by arrows. Plasma amino acid concentrations are shown on the middle graph: methionine, $\square--\square$; homocystine, - Pyridoxine administration is indicated by the dotted rectangle at the bottom of the graph. The dose of $200 \mathrm{mg}$ /day was continued through day 175. Folic acid was administered from day 157 through 175.

methionine and cystine that he ate when he was fed ad lib. Plasma concentration and the daily urinary excretion of homocystine were observed during control periods and during pyridoxine administration. In each case, pyridoxine treatment led to a prompt decrease in plasma and urinary homocystine and in plasma methionine (Figs. 2-4). Upon discontinuation of the pyri- doxine, there was a return to the pretreatment state (Fig. 3).

Oral methionine, administered to the cystathionine synthase-deficient patients not on pyridoxine therapy, caused a prolonged increase in plasma methionine concentration but no rise in either plasma or urinary homocystine (Figs. 2-4). This somewhat paradoxical failure

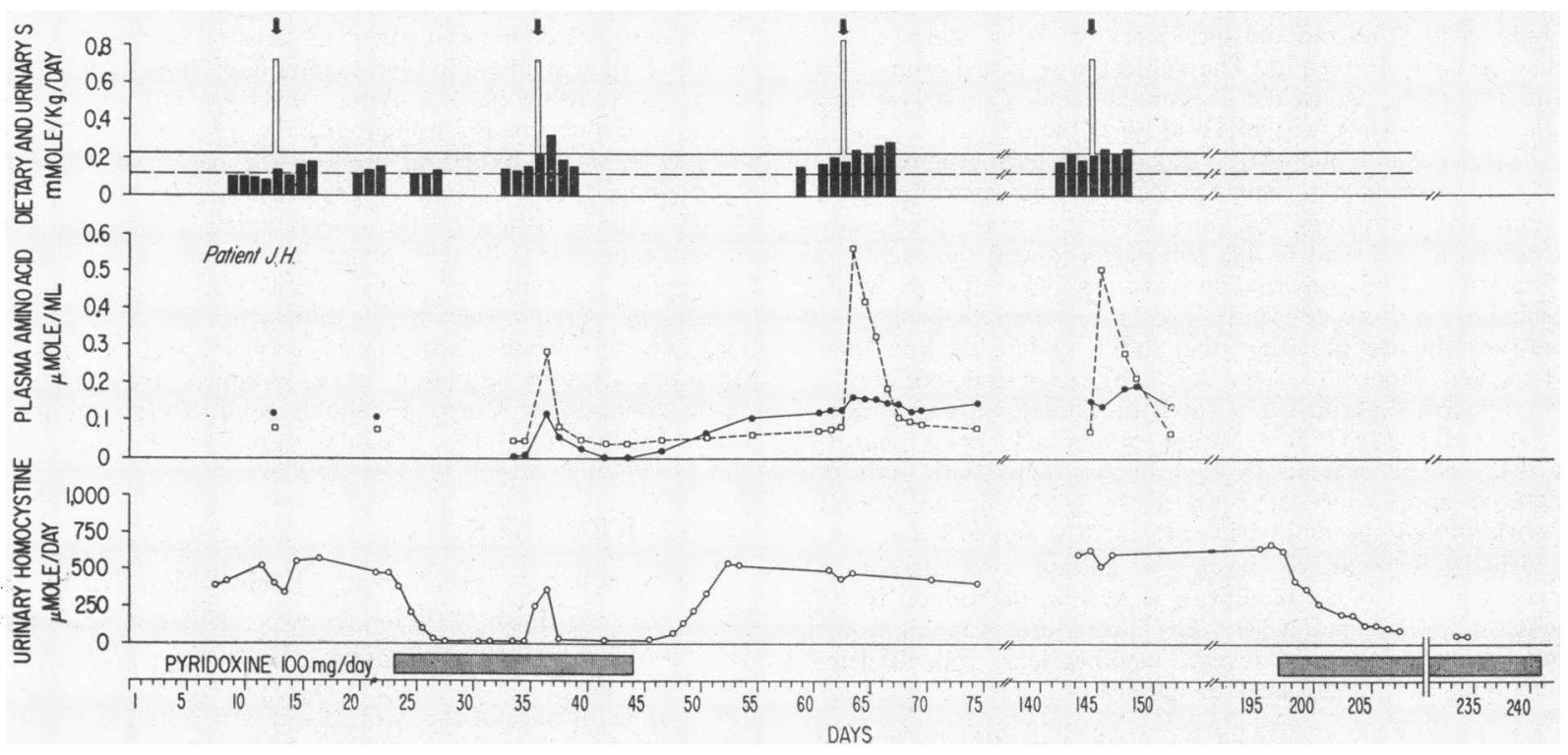

FIGURE 3 Effect of pyridoxine and of L-methionine administration in cystathionine synthasedeficient patient, J. H. See legend to Fig. 2 for explanation. 

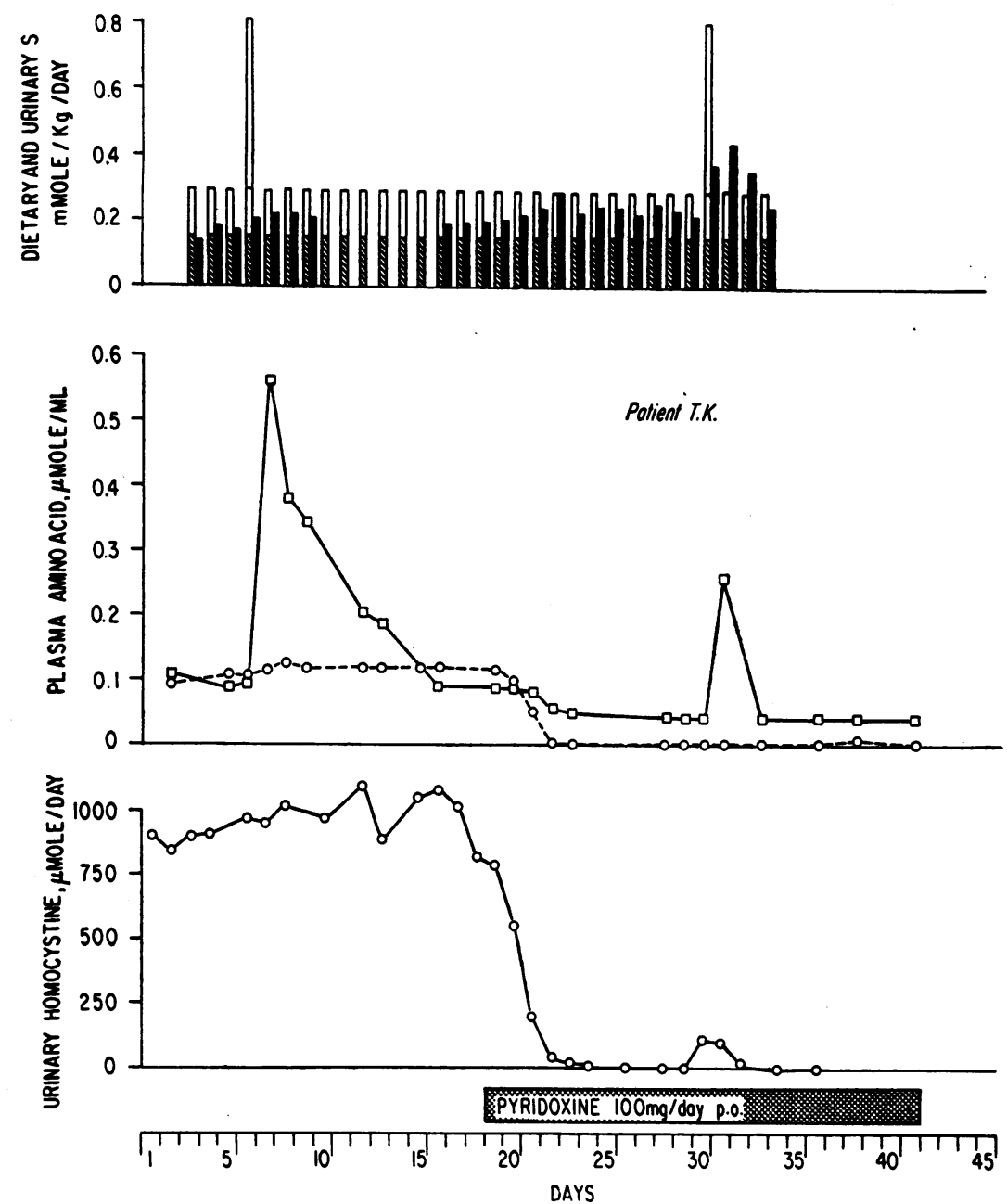

FIGURE 4 Effect of pyridoxine and of L-methionine administration in cystathionine synthase-deficient patient, T. K. Symbols are the same as those in Fig. 2 with the following exceptions. Intake of cystine is represented by the crosshatched rectangles; intake of methionine, by the open rectangles. Supplementary oral methionine doses are shown by the higher open rectangles. Plasma amino acid concentrations are shown on the middle graph: methionine, $\square-\square$; homocystine, $\bigcirc---\bigcirc$.

of homocystine to increase under these conditions has been noted and discussed previously (24). During pyridoxine treatment, several differences were apparent in the response to a methionine load. Methionine disappeared from the plasma more rapidly, and there was now a rise in urinary homocystine in all three patients and a rise in plasma homocystine in both $\mathrm{K}$. B. and J. H.

Effect of pyridoxine on urinary excretion of other sulfur-containing amino acids. For each patient the administration of pyridoxine was accompanied by a reduction in urinary excretion of methionine, homo- cystine, mixed homocysteine-cysteine disulfide, and homolanthionine (Table I). Cystine excretion increased somewhat. The same changes for cystine were found with both chromatographic systems, A and B. Each patient excreted small amounts of material which chromatographed in both systems A and B with authentic cystathionine. The excretion of this material decreased during pyridoxine response. However, acid hydrolysis or preparative chromatography followed by peroxide oxidation and rechromatography showed that under all conditions there was excretion of no more than traces of cystathionine of questionable significance. Thus, cys- 
TABLE I

Excretion of Sulfur-Containing Amino Acids during Control Periods and Pyridoxine Response

\begin{tabular}{|c|c|c|c|c|c|c|c|}
\hline Subject & Pyridoxine & $\begin{array}{c}\text { Experimental } \\
\text { day }\end{array}$ & Methionine & Homocystine* & $\begin{array}{c}\text { Mixed } \\
\text { disulfide* }\end{array}$ & $\begin{array}{l}\text { Homolan- } \\
\text { thionine* }\end{array}$ & $\frac{1}{2}$ Cystine \\
\hline & & & umoles/day & $\boldsymbol{\mu m o l e s / d a y}$ & 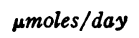 & umoles/day & umoles/day \\
\hline \multirow[t]{4}{*}{ K. B. } & None & 28 & 99 & 458 & 120 & 53 & 53 \\
\hline & $"$ & 33 & 104 & 543 & 116 & 57 & 53 \\
\hline & $200 \mathrm{mg} /$ day & 87 & 50 & 55 & 69 & 18 & 86 \\
\hline & $" \quad " \quad$ & 90 & 49 & 65 & 87 & 32 & 95 \\
\hline \multirow[t]{4}{*}{ J. H. } & None & 12 & 114 & 535 & 114 & 65 & 50 \\
\hline & $"$ & 22 & 109 & 480 & 100 & 67 & 58 \\
\hline & $100 \mathrm{mg} /$ day & 31 & 21 & 13 & 20 & 4 & 93 \\
\hline & " " " & 34 & 24 & 15 & 21 & 4 & 98 \\
\hline \multirow[t]{4}{*}{ T. K. } & None & 1 & 101 & 895 & 204 & 98 & 88 \\
\hline & " & 2 & 96 & 838 & 187 & 82 & 84 \\
\hline & $100 \mathrm{mg} /$ day & 39 & 40 & $<10$ & 16 & 6 & 159 \\
\hline & $" \quad " \quad$ & 40 & 32 & $<10$ & 17 & 6 & 152 \\
\hline
\end{tabular}

* The structural formulas of some of the compounds mentioned are: homocystine, $\mathrm{HOOCCHCH}{ }_{2} \mathrm{CH}_{2}-\mathrm{S}-\mathrm{S}-\mathrm{CH}_{2} \mathrm{CH}_{2}$ I $\mathrm{NH}_{2}$ $\mathrm{CHCOOH}$; mixed disulfide of cysteine and homocysteine, $\mathrm{HOOCCHCH} \mathrm{CH}_{2}-\mathrm{S}-\mathrm{S}-\mathrm{CH}_{2} \mathrm{CHCOOH}$; cystathionine, 1 $\mathrm{NH}_{2}$ $\stackrel{1}{\mathrm{NH}_{2}} \stackrel{\mathrm{NH}}{\mathrm{NH}_{2}}$ $\mathrm{HOOCCHCH}{ }_{2} \mathrm{CH}_{2}-\mathrm{S}-\mathrm{CH}_{2} \mathrm{CHCOOH}$; homolanthionine, $\mathrm{HOOCCHCH} \mathrm{CH}_{2}-\mathrm{S}-\mathrm{CH}_{2} \mathrm{CH}_{2} \mathrm{CHCOOH}$.<smiles>NCCN</smiles>
$\mathrm{NH}_{2}$ $\mathrm{NH}_{2}$

tathionine excretion was too low to be measured quantitatively either before or during pyridoxine administration.

Complex formation between homocysteine and pyridoxal or pyridoxal phosphate; absence of these complexes from urine of patients during pyridoxine response. Pyridoxal derivatives react with amino thiols such as homocysteine at neutral $\mathrm{pH}$ to form thiazolidine compounds $(25,26)$. To examine the possibility that pyridoxine exerts its effect on patients with cystathionine synthase deficiency by giving rise to an aldehyde derivative which forms a readily excreted complex with homocysteine, we incubated pyridoxal at neutral $\mathrm{pH}$ with amounts of homocysteine from 1 to 100 mole equivalents. In each case, there was virtually quantitative conversion of pyridoxal to a ninhydrin-reactive compound, presumably a complex containing 1 mole of homocysteine and 1 mole of pyridoxal, which migrated in chromatography system $\mathrm{A}$ to a position about $14 \mathrm{~min}$ after the homocysteine peak (i.e., emerging about 61 min before the elution of homocystine). In similar experiments with pyridoxal phosphate and homocysteine the major product eluted from the column after $29 \mathrm{~min}$, as would be expected for an acidic complex of homocysteine with pyridoxal phosphate. The complex of homocysteine with either pyridoxal or pyridoxal phos- phate was not detected in urine from any of the three patients during pyridoxine response. Complex would have been readily apparent had it been present at a concentration sufficient to balance even a small portion of the decrease in homocystine excretion.

Lack of keto acid analogue of methionine in urine of patients during pyridoxine response. Fresh-voided urine specimens, aliquots of $24-\mathrm{hr}$ collections, or both, from control subjects and from patients T. K., J. H., and $\mathrm{D}$. F. during pyridoxine response were examined for keto acid content by treatment with 2,4-dinitrophenylhydrazine and paper chromatography of the resulting 2,4-dinitrophenylhydrazones (22). In each case, 2,4-dinitrophenylhydrazones corresponding to these of $\alpha$-ketoglutarate and pyruvate were readily detected. These are the chief keto acids excreted by normal humans (27). In no case was a spot detected which corresponded in its paper chromatographic properties to those of the authentic 2,4-dinitrophenylhydrazone of $\alpha$-keto- $\gamma$-methylthiobutyrate. The sensitivity of the experiments was sufficient to have detected an excretion of $40 \mu$ moles/day of this keto acid analogue of methionine.

Effect of pyridoxine on hepatic cystathionine synthase activity. The hepatic cystathionine synthase activity of $\mathrm{K}$. B. was $3 \mathrm{U} / \mathrm{mg}$ of protein before she was given pyridoxine (5) and $10.4 \mathrm{U} / \mathrm{mg}$ of protein when she was re- 
TABLE II

Hepatic Enzyme Activities in Control Subjects and in Homocystinuric Subjects before and after Administration of Pyridoxine

\begin{tabular}{|c|c|c|c|}
\hline $\begin{array}{c}\text { Subject } \\
\text { and date }\end{array}$ & $\begin{array}{l}\text { Pyridoxal } \\
\text { phosphate* }\end{array}$ & $\begin{array}{l}\text { Cysta- } \\
\text { thionine } \\
\text { synthase }\end{array}$ & $\begin{array}{l}\text { Cysta- } \\
\text { thionase }\end{array}$ \\
\hline & umoles & $U / m g$ & $\begin{array}{c}\text { mumoles/ } \\
\text { mg per } \\
30 \text { min }\end{array}$ \\
\hline Control subjects & - & $252 \ddagger$ & $13 \S$ \\
\hline $\begin{array}{l}\text { J. H. } \\
\qquad \begin{array}{l}1965 \\
11 / 20 / 68 \|\end{array}\end{array}$ & $\begin{array}{l}0.015 \\
0.4\end{array}$ & $\begin{array}{l}5.0 \\
7.6\end{array}$ & $\begin{array}{r}17.5 \\
9.1\end{array}$ \\
\hline $\begin{array}{l}\text { K. B. } \\
\qquad \begin{array}{l}1965 \\
9 / 10 / 68 \|\end{array}\end{array}$ & $\begin{array}{l}0.015 \\
\text { None } \\
0.015 \\
0.4 \\
1.2\end{array}$ & $\begin{array}{r}3.0 \\
10.5 \\
11.6 \\
10.4 \\
10.4\end{array}$ & \\
\hline
\end{tabular}

* Amount of pyridoxal phosphate added to standard incubation mixture of $0.40 \mathrm{ml}$ for assay of cystathionine synthase. $\ddagger$ Mean of nine values (range 133-610) as previously published (28). (A unit of activity is defined in Methods.) The specific activity of cystathionine synthase in control liver extracts is essentially independent of addition of pyridoxal phosphate over the range shown in this table.

$\S$ Mean of five values (range 6-18.5) as previously published (28).

\| The 1968 biopsies were obtained when the patients were receiving pyridoxine. K. B. was biopsied on day 138 (Fig. 2). Her plasma contained only a trace of homocystine, and her urinary homocystine excretion during the preceding $24 \mathrm{hr}$ was at the low value of $64 \mu$ moles. J. H. was biopsied on day 238 (Fig. 3). Her urinary homocystine excretion was approximately $45 \mu$ moles/day.

ceiving the drug (Table II). The activity in the second sample from K. B. was the same whether pyridoxal phosphate was omitted from the assay medium or whether its concentration was increased to a value as high as $3 \mathrm{~mm}$. The values for $\mathrm{J}$. H. were 5 (5) and $7.6 \mathrm{U} / \mathrm{mg}$ of protein before and during pyridoxine treatment. All these specific activities are extremely low compared with control values (Table II).

To ensure that the assay of cystathionine synthase was valid when used to determine such low levels of activity, the assay with the extract of liver obtained from $\mathrm{J} . \mathrm{H}$. before pyridoxine treatment was repeated with serine ${ }^{14} \mathrm{C}$ of higher than usual specific radioactivity. The reaction product was isolated by column chromatography and subjected to paper chromatography in two solvent systems before and after oxidation with hydrogen peroxide. Before oxidation the radioactive reaction product had chromatographic properties iden- tical with those of authentic cystathionine; after oxidation, the radioactive material migrated identically with the oxidation product of cystathionine. Representations of these chromatograms have previously been published (Fig. 3 in reference 23 ).

The specimen from J. H. was assayed for a second enzyme activity, cystathionase (catalyzing step 5, Fig. 1). A value of $9.1 \mathrm{U} / \mathrm{mg}$ of protein was determined (Table II). The value determined $3 \mathrm{yr}$ previously when she was not taking pyridoxine was $17.5 \mathrm{U} / \mathrm{mg}$ (23).

Properties of cystathionine synthase. The cystathionine synthase activity in extracts of liver obtained from the homocystinuric patients during pyridoxine response did not differ from the activity in liver of control subjects with respect to the following properties.

(a) Trypsin activation. Cystathionine synthase activity of crude control human liver extracts is increased about 1.5 - to 3 -fold by treatment with trypsin. Cystathionine synthase activity in the extracts from patients $\mathrm{K}$. B. and J. H. was stimulated in a similar manner by trypsin treatment (Table III), but it remained far below control values.

The trypsin treatment was useful because after activation there was enough cystathionine synthase activity in the limited material from the deficient patients to

TABLE III

The Effect of Trypsin Treatment on Cystathionine Synthase Activity of Liver Extracts from the Control Subjects and Cystathionine Synthase-Deficient Patients

\begin{tabular}{cccc}
\hline & \multicolumn{2}{c}{ Cystathionine synthase } \\
\cline { 2 - 3 } Subject & (a) Untreated & $\begin{array}{c}\text { (b) Trypsin } \\
\text { treatment }\end{array}$ & Ratio $\frac{(\mathrm{b})}{(\mathrm{a})}$ \\
\hline Controls & \multicolumn{3}{c}{$U / m g$} \\
K. L. & 211 & 452 & 2.1 \\
P. G. & 173 & 452 & 2.6 \\
K. M. & 248 & 514 & 1.9 \\
J. T. & 103 & 265 & 2.6 \\
Patients & & & \\
K. B. & 9.4 & 28.5 & 3.0 \\
J. H. & 7.6 & 21.3 & 2.7 \\
\hline
\end{tabular}

Liver extracts were incubated with $5.0-7.0 \mu \mathrm{g}$ of trypsin per $\mathrm{mg}$ extract protein in potassium phosphate buffer for $30 \mathrm{~min}$ at $23^{\circ} \mathrm{C}$. An amount of crystalline pancreatic trypsin inhibitor equal to the amount of trypsin used was added, and the preparation was assayed for cystathionine synthase activity. In control experiments, it was shown that trypsin and trypsin inhibitor in these amounts are free of cystathionine synthase activity. Control specimens were obtained from patients K. L., P. G., and K. M. undergoing laparotomy for extrahepatic disease. The specimen from J. T. was obtained at postmortem examination. K. B. and J. H. are the cystathionine synthasedeficient patients. 
TABLE IV

Heat Inactivation and Pyridoxal Phosphate Stabilization of Cystathionine Synthase Activity in Liver Extracts from the Control Subjects and Cystathionine Synthase-Deficient Patients

\begin{tabular}{cccccc}
\hline \multirow{2}{*}{$\begin{array}{c}\text { Heat } \\
\text { treatment }\end{array}$} & $\begin{array}{c}\text { Pyridoxal } \\
\text { phosphate }\end{array}$ & \multicolumn{4}{c}{ Cystathionine synthase activity } \\
\cline { 3 - 6 } & K. L. & P. G. & K. B. & J. H. \\
\hline $\min$ & $m M$ & \multicolumn{4}{c}{ \% of unheated control } \\
4 & 0 & 44 & 34 & 52 & 44 \\
25 & 0 & 6 & 6 & 5 & 1 \\
25 & 0.15 & 37 & 30 & 23 & 15 \\
25 & 0.50 & 73 & 69 & 56 & 38 \\
\hline
\end{tabular}

All liver extracts were activated by trypsin, then treated by

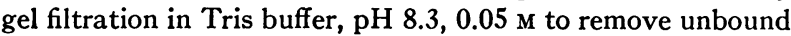
low molecular weight compounds. Pyridoxal phosphate was then added at the final millimolar concentration shown. The extracts were heated at $59^{\circ} \mathrm{C}$ as specified and cooled, and the entire preparation was assayed for cystathionine synthase activity. K. L. and P. G. were control subjects; K. B. and $\mathrm{J}$. H. were homocystinuric. In control experiments, it was shown that trypsin activation did not markedly affect the response of cystathionine synthase activity from a control subject to heat inactivation or pyridoxal phosphate stabilization.

allow more experiments to be carried out than would otherwise have been possible. Therefore, the next sets of experiments were performed with trypsin-treated enzymes.

(b) Heat inactivation and stabilization by pyridoxal phosphate. Cystathionine synthase activity in the patients was not more labile during heat treatment than was the activity from control subjects (Table IV). Cystathionine synthase activity is stabilized to heat inactivation by the presence specifically of pyridoxal phosphate. This is true even of holoenzyme preparations which have full catalytic activity in the absence of added pyridoxal phosphate." Pyridoxal phosphate was almost as effective in stabilization of enzyme from the patients as in stabilization of enzyme from control subjects (Table IV).

(c) Effect of increase in serine concentration upon cystathionine synthase activity. Under our usual assay conditions, cystathionine synthase activity is partially limited by the concentration of the substrate serine. The possibility that the low activity measured in the patients was caused by an abnormally low affinity for serine was excluded by the observation that increasing the serine concentration by 5.2 -fold increased both the normal enzyme activity and enzyme activity from a patient by about 1.5 -fold (Table V).

'Mudd, S. H., and B. Conerly. Unpublished observations.
Effect of pyridoxine on conversion of the sulfur of methionine to inorganic sulfate. A normal subject fed a single dose of L-methionine promptly increases his urinary excretion of inorganic sulfate. During the first day, the amount of urinary inorganic sulfate in excess of that excreted daily during the control period is equivalent to $70 \% \pm 4$ (mean \pm SEM) (24) of the sulfur in the L-methionine. Results of representative studies on control subjects showing this response are presented in Fig. 5. When these subjects were given pyridoxine and studied again, their responses were the same (Fig. 5 ). We showed previously that subjects with cystathionine synthase deficiency have a diminished capacity to increase urinary excretion of inorganic sulfate after an oral dose of L-methionine (24). This diminished response was observed also with the patients in the present study (Figs. 2-5).

To determine whether pyridoxine affects this response to oral methionine, the patients were studied a second time during pyridoxine administration. In each case the ability to excrete the sulfur of L-methionine as inorganic sulfate remained far below normal, although definite increases in this ability were observed. Oral folic acid therapy, which may affect the balance between the excretion of homocystine and methionine (29), did not alter the response to a methionine load (Fig. 3).

Estimates of the capacity to metabolize methionine. The data on inorganic sulfate excretion presented in Figs. 2-5 can be used to calculate the capacity to metabolize methionine to inorganic sulfate. Thus, K. B., during the experiment performed on day 7 (Fig. 2) converted approximately $126 \mu$ moles $/ \mathrm{kg}$ per $24 \mathrm{hr}$ of methionine sulfur to inorganic sulfate $(46 \mu$ moles from the added methionine load and $80 \mu$ moles from dietary methionine; the latter figure was derived on the assumption that the basal inorganic sulfate excretion is composed of contributions from dietary methionine and cys-

TABLE V

Effect of Increased Serine Concentration on Cystathionine Synthase Activity in Liver Extracts from Control Subjects and a Cystathionine SynthaseDeficient Patient

\begin{tabular}{lc}
\hline Liver extract & $\begin{array}{c}\text { Ratio of } \\
\text { enzyme } \\
\text { activities* }\end{array}$ \\
\hline Control & 1.6 \\
Control (trypsin treated) & 1.5 \\
Patient K. B. (trypsin treated) & 1.5
\end{tabular}

* Each extract was assayed with serine added at $2.5 \mathrm{mM}$ (the standard concentration) and $13.0 \mathrm{~mm}$. The ratio of specific activity at the higher serine concentration to specific activity at the lower serine concentration is shown. 


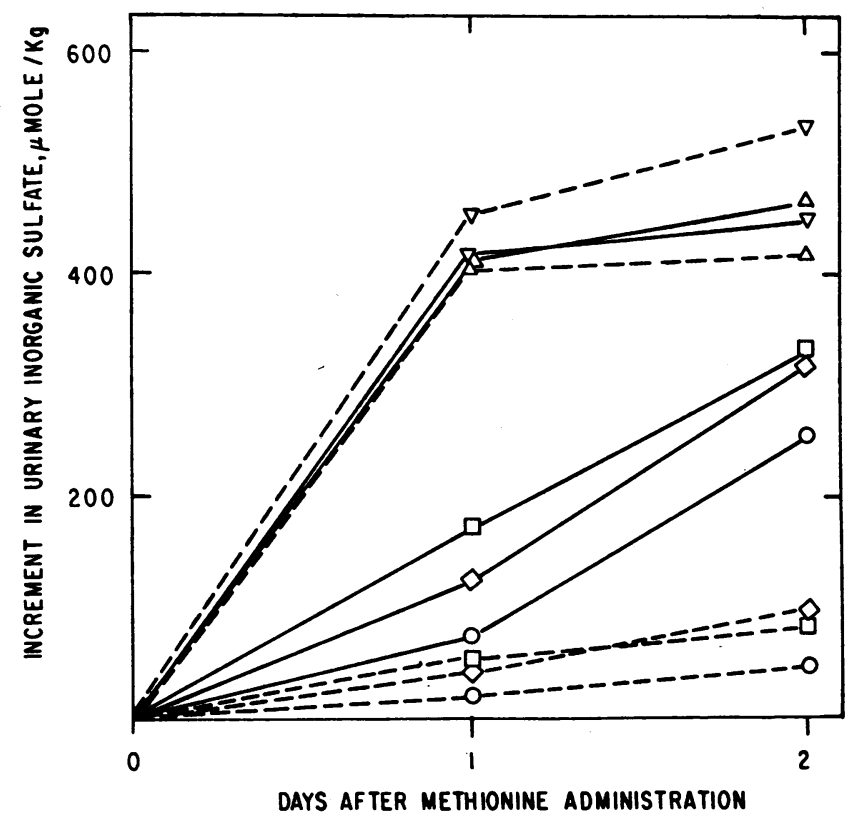

FIGURE 5 Cumulative increment in inorganic sulfate excretion for 2 days after an oral dose of L-methionine. Dashed lines, subjects not taking supplemental pyridoxine; solid lines, subjects taking supplemental pyridoxine; control subject V. P., $\triangle$; control subject D. G., $\nabla$; patient $\mathrm{K}$. B., $\square$; patient J. H., O; patient T. K., $\diamond$. A cumulative increment of $500 \mu \mathrm{mole} / \mathrm{kg}$ would represent excretion of the sulfur of the entire supplemental dose of L-methionine.

tine in proportion to the relative intakes of the two amino acids [24]). Likewise, J. H. converted 110 $\mu$ moles $/ \mathrm{kg}$ per $24 \mathrm{hr}$. The mean of these two values is $118 \mu$ moles $/ \mathrm{kg}$ per $24 \mathrm{hr}$. For a $70 \mathrm{~kg}$ individual this is equivalent to a total capacity of $8.3 \mathrm{mmoles} / 24 \mathrm{hr}$, slightly less than the expected methionine intake of about $10 \mathrm{mmoles} /$ day. During pyridoxine administration, the conversion rates were 246 and $214 \mu$ moles $/ \mathrm{kg}$ per $24 \mathrm{hr}$, equivalent to a mean total capacity of 16.1 mmoles $/ 24 \mathrm{hr}$ for a $70 \mathrm{~kg}$ person. Both rates, of course, are below those attained by normal subjects who can convert at least 70 mmoles $/ 24 \mathrm{hr}$ (24).

The conversion rates may be related to the measured specific activities of cystathionine synthase, as shown in Table VI, to yield estimates of conversion rates per unit of hepatic enzyme specific activity. For homocystinuric patients in whom cystathionine synthase activity is clearly rate-limiting, such values can be regarded as upper limits for the conversion corresponding to each specific activity unit of cystathionine synthase if it be assumed that all conversion is occurring via the cystathionine pathway and that no alternate metabolic pathway is contributing.

The conversion rate corresponding to each specific activity unit of cystathione synthase may be estimated also from in vitro assays. Each unit of activity is equivalent to $1 \mathrm{~m} \mu \mathrm{mole} / \mathrm{mg}$ of protein per $135 \mathrm{~min}$. In $24 \mathrm{hr}$, this would represent formation of $1 \times 60 / 135$ $\times 24=10.7 \mathrm{~m} \mu \mathrm{mole} / \mathrm{mg}$ of protein or $10.7 \times 10^{-3} \mu \mathrm{mole} /$ $\mathrm{mg}$ of protein. A liver weighing $1500 \mathrm{~g}$ with $10 \%$ soluble protein would contain $1500 \times 0.1 \times 10^{3}=150 \times 10^{\circ}$

TABLE VI

Rates of Conversion of Methionine Sulfur to Inorganic Sulfate by Cystathionine Synthase Deficient Patients before and during Pyridoxine Therapy

\begin{tabular}{|c|c|c|c|c|}
\hline Patient & $\begin{array}{l}\text { Pyridoxine } \\
\text { therapy }\end{array}$ & $\begin{array}{l}\text { Conversion } \\
\text { of } \\
\text { methionine } \\
\mathrm{S} \text { to SO. } \\
=\text { (a) }\end{array}$ & $\begin{array}{l}\text { Cysta- } \\
\text { thionine } \\
\text { synthase } \\
\text { activity } \\
\text { (b) }\end{array}$ & $\begin{array}{l}\text { Conversion } \\
\text { per unit } \\
\text { specific } \\
\text { activity } \\
\text { (a) } /(\text { b) }\end{array}$ \\
\hline & & $\begin{array}{l}\text { umole } / \mathrm{kg} \\
\text { per } 24 \mathrm{hr}\end{array}$ & $\begin{array}{c}\text { specific } \\
\text { activity } \\
\text { units }\end{array}$ & $\begin{array}{l}\text { mmole } / \mathrm{kg} \\
\text { per } 24 \mathrm{hr} \\
\text { per specific } \\
\text { activity unit }\end{array}$ \\
\hline K. B. & - & 126 & 3 & 42 \\
\hline K. B. & + & 246 & 10.7 & 23 \\
\hline J. H. & - & 110 & 5 & 22 \\
\hline J. H. & + & 214 & 7.6 & 28 \\
\hline
\end{tabular}


mg of protein. The total hepatic cystathionine synthase capacity would then be $10.7 \times 10^{-3} \times 150 \times 10^{3}=1600$ $\mu$ mole $/ 24 \mathrm{hr}$. Converting to a per kilogram basis, we obtain a value of $1600 / 70=23 \mu \mathrm{mole} / \mathrm{kg}$ per $24 \mathrm{hr}$ per specific activity unit. This figure is based on an in vitro assay carried out at the optimum $\mathrm{pH}, 8.3$, and with serine partially limiting. To adjust the value to one more nearly corresponding to physiological conditions, it should be revised to about $23 \times 0.4=9.2$ to correspond to activity at $\mathrm{pH} 7.4$. It is less clear how to adjust for the serine concentration. We are not aware of any reported measurement of tissue serine concentration in a cystathionine synthase deficient patient, but if this substrate accumulates also to near saturating concentrations, the value for hepatic capacity should be increased to $9.2 \times 1.7=16 \mu \mathrm{mole} / \mathrm{kg}$ per $24 \mathrm{hr}$ per specificity activity unit. The body's total capacity to synthesize cystathionine includes, in addition to the hepatic capacity, a relatively small contribution from other organs. (A very rough estimate, based on a tissue survey of cystathionine synthase activity [23] is that other organs together synthesize about one-half as much cystathionine as does the liver.) Thus, the final estimate of the total capacity is somewhat more than $16 \mu$ mole $/ \mathrm{kg}$ per $24 \mathrm{hr}$ per specific activity unit, an estimate in reasonable agreement with the values derived in Table VI on the basis of different assumptions and measurements.

\section{DISCUSSION}

Any hypothesis concerning the mechanism by which pyridoxine affects patients with cystathionine synthase deficiency must explain the changes observed in plasma concentrations and urinary excretions of the sulfur amino acids during pyridoxine response. Homocystine, methionine, homocysteine-cysteine mixed disulfide, and homolanthionine all decrease, as shown in this study (Table I) and in others $(3,6,7,9,12,13,15-17) .^{5}$ Each of these compounds derives metabolically from homocysteine by reactions preceding the block at the cystathionine synthase step. ${ }^{\circ}$ Conversely, there is an increase in plasma $(6,9,12,14-16)$ and urinary (Table I) cystine, the first metabolite measurable (in these patients) distal to the metabolic block. This combination of changes is readily explained by an hypothesis that pyridoxine enhances cystathionine synthase activity. In addition, these changes make it unlikely that pyridoxine

\footnotetext{
SThe effect of pyridoxine upon homolanthionine excretion has been mentioned in only one other study (30). The results are difficult to interpret because of intercurrent penicillamine treatment and probable $B_{8}$ deficiency.

${ }^{\circ} \mathrm{S}$. H. Mudd, unpublished observations, has obtained evidence that homolanthionine arises from homocysteine and homoserine in a reaction catalyzed by an enzyme other than cystathionine synthase, most probably cystathionase.
}

lessens homocystine accumulation by interfering with a step in the conversion of methionine to homocysteine.

No positive evidence favors the possibility that pyridoxine activates an alternate (normally minor) pathway, either chemical or enzymatic, for removal of homocysteine and/or its metabolites. Neither we nor others have found new metabolites (for example $\alpha$-keto- $\gamma$ methylthiobutyrate or the complex of homocysteine with pyridoxal phosphate) which might have appeared in urine or plasma had an alternate pathway become important. It is unlikely that desulfhydration of homocysteine is increased by administration of pyridoxine in view of the finding that the activity of cystathionase (the enzyme which catalyzes homocysteine desulfhydration in rat liver [31]) was not higher in the liver of J. H. during pyridoxine response than it had been several years previously when the patient was receiving only the $\mathrm{B}_{\mathrm{e}}$ contained in her normal diet. Further evidence to sustain this conclusion comes from the studies of Gaull, Rassin, and Sturman (9). These workers obtained serial liver biopsies during a brief period and found that pyridoxine administration led to a severalfold increase in the specific activity of hepatic cystathionase. However, this increase could not account for the decrease in homocystinemia and methioninemia because, when $\mathrm{B}_{\boldsymbol{c}}$ administration to two of the patients was discontinued, the plasma homocystine and methionine reverted to elevated levels despite the fact that cystathionase specific activity remained high. Thus, no evidence has as yet been forthcoming which indicates that pyridoxine may be effective through activation of an alternate pathway.

In spite of these reasons for believing that pyridoxine might act by enhancement of cystathionine synthase activity, direct studies of the enzyme were, at first, discouraging to this point of view. In almost all instances, in vitro addition of pyridoxal phosphate to extracts of liver (4-6, 8-10) or fibroblasts (11) from homocystinuric patients has failed to restore cystathionine synthase activity to more than a few per cent of normal. (A single exceptional case has been reported by Yoshida, Tada, Yokoyama, and Arakawa [7] in which such addition stimulated activity to $31 \%$.) Furthermore, our present results show that even in liver samples obtained from homocystinuric patients during pyridoxine response, the cystathionine synthase activity is no more than $3-4 \%$ of normal, whether or not pyridoxal phosphate is added in vitro. During the course of our studies, two other laboratories have reported assays of hepatic cystathionine synthase in homocystinuric patients during response to pyridoxine $(6,8,9)$. Cystathionine synthase activity was not detected, even when excess pyridoxal phosphate was added in vitro. Since the assay methods used in these studies differed somewhat 
from ours and since no sensitivities for detection of low activities of cystathionine synthase were reported, it is not clear whether cystathionine synthase activity was entirely absent or whether activities of a few per cent of normal, such as we observed in our patients, were present. $^{7}$

Pyridoxine administration does not lead to restoration of normal cystathionine synthase activity in the liver of patients with cystathionine synthase deficiency. Yet in each patient we studied, during pyridoxine response the cystathionine synthase activity was somewhat higher than it had been previously, rising from 1 to $2 \%$ of normal to from 3 to $4 \%$. What metabolic consequence would be anticipated if a patient with a small residual activity of cystathionine synthase were stimulated to increase this activity somewhat? The measurements of inorganic sulfate excretion after methionine loads and the estimates of the total body capacity to metabolize methionine derived from these measuremen ${ }^{+} \mathrm{s}$ show that a cystathionine synthase-deficient patient not on pyridoxine treatment may convert at most about 8 mmoles of methionine sulfur to inorganic sulfate each day. This is somewhat less than the expected dietary intake of about 10 mmoles. On pyridoxine, the same patient may convert about 16 mmoles, a little more than his daily intake. No proof is provided that this me.hionine is being metabolized via the cystathionine pathway. Conceivably, an alternate pathway contributes. Nevertheless, the relative consistency of the estimates of the maximum metabolic capacity corresponding to each unit of cystathionine synthase, based either on measurements of inorganic sulfate excretion (Table VI) or on in vitro enzyme assay, make it reasonable to suggest that the cystathionine pathway does indeed account for the observed methionine metabolism. Furthermore, by use of the mean value of the four estimates in Table VI, $28.8 \mu$ moles $/ \mathrm{kg}$ per $24 \mathrm{hr}$ per specific activity unit, it can be calculated that a subject with the mean control specific activity of $252 \mathrm{U} / \mathrm{mg}$ of hepatic cystathionine synthase should be able to metabolize $28.8 \times 252 \times 10^{-8}=7.3$ mmoles of homocysteine $/ \mathrm{kg}$ per $24 \mathrm{hr}$, whereas individuals heterozygous for cystathionine synthase deficiency, with a mean specific activity of 92 (5), should be able to metabolize $28.8 \times 92 \times 10^{-8}=2.6$

${ }^{7}$ Fibroblasts grown from skin biopsies of the patients studied by Hollowell, Corywell, Hall, Findley, and Theraos (6) contained measurable cystathionine synthase activities. The activities were $1 \%$, or less, of the mean control value. (B. W. Uhlendorf and S. H. Mudd. Unpublished observations). Gaull et al. (9) report a cystathionine synthase activity in one homocystinuric patient equal to about $3 \%$ of their mean control activity (Table II, reference 9). Yet, in the text, they say there was no activity of cystathionine synthase in this patient. These facts suggest the sensitivity of their assay method is insufficient to quantitate a few per cent of normal activity. mmoles $/ \mathrm{kg}$ per $24 \mathrm{hr}$. Both these predictions have been borne out experimentally since the maximum doses of methionine which we have felt justified in giving to such individuals (up to almost $1.2 \mathrm{mmoles} / \mathrm{kg}$ per day) were converted into inorganic sulfate just as efficiently as lower doses (24). Such experiments provide further evidence that the estimates of the metabolic capacity of each unit of cystathionine synthase are reasonable and that it is possible, tentatively, to ascribe the pyridoxine response in the cystathionine synthase-deficient patients we studied to the small observed increases in residual cystathionine synthase activities. Clearly, this conclusion is not rigorously proven. The greatest difficulty in obtaining a final answer is not the approximate nature of the analysis or the experimental error in measuring low enzyme activities. (The error in the enzyme assay carried out by our method is small compared to the changes in question, Table II.) Rather, the difficulty lies in demonstrating that the small changes observed while the patients were receiving pyridoxine persist while therapy with this drug is continued and disappear when the drug is withdrawn. It must be shown that the changes are not the result of fortuitous biological variation. Such a demonstration would require a grea+er number of liver biopsies than we feel are warranted. Possibly, study of fibroblasts from cystathionine synthase-deficient patients will permit further clarification of this problem.

A small change in the activity of an enzyme (which, as in the present case, may be difficult to establish as unequivocally due to a given therapeutic agent) may be of great physiological importance if the reserve capacity of the normal liver is great enough. In the present instance, a rise in cystathionine synthase activity from 1 to $2 \%$ of normal to from 3 to $4 \%$ of normal may enable the body to metabolize the normal daily load of dietary methionine without excessive accumulation of intermediates proximal to the reaction catalyzed by cystathionine synthase. A continued search for agents which stimulate enzyme activity appears to be warranted not only in cystathionine synthase deficiency but also in other diseases due to deficiencies of enzyme activity.

If pyridoxine administration does indeed lead to a small enhancement of cystathionine synthase activity, further studies will be required to ascertain the mechanism of this enhancement. Although pyridoxal phosphate is generally regarded as a cofactor for cystathionine synthase, recent studies have yielded conflicting results as to its role in the activity of cystathionine synthase of rat liver (32-34). With the human liver enzyme, a partially purified preparation has been obtained which is completely dependent for activity upon pyridoxal phosphate. Other phosphorylated $\mathrm{B}_{\mathrm{o}}$ derivatives were less 
effective, whereas nonphosphorylated forms were completely inactive (35). While these studies do not provide final proof that pyridoxal phosphate is part of the native holoenzyme, it is clear that pyridoxal phosphate can activate cystathionine synthase. The studies reported in Table IV suggest one means whereby pyridoxal phosphate could enhance the physiological concentration of active cystathionine synthase-by stabilization of enzyme protein. However, other mechanisms must be considered. A possibly analogous case is the stimulation of tyrosine transaminase activity brought about by large doses of pyridoxine (36) which stimulate apoenzyme synthesis (37).

Regardless of the mechanism whereby pyridoxine acts in cystathionine synthase-deficient patients, not only homocystine, but also methionine, homolanthionine, and homocysteine-cysteine mixed disulfide are all lowered toward more normal concentrations during pyridoxine response. If one or more of these substances contributes to the pathology of cystathionine synthase deficiency, pyridoxine treatment might be beneficial. No increase in abnormal metabolites has been detected. Pending final clarification of the mechanism of the pyridoxine effect, it would seem reasonable to maintain on pyridoxine those patients who respond favorably and to recommend in addition either a low methionine diet or, if that is not feasible, at least that food be taken in small frequent meals to avoid sudden large increments in dietary methionine.

\section{ACKNOWLEDGMENTS}

We are grateful to Doctors Victor McKusick and Judith Hall of Johns Hopkins Hospital for referring patients K. B. and J. H. to us, Dr. John Littlefield of the Massachusetts General Hospital for referring patient T. K. to us, and Dr. Vivian Shih for sending us a urine specimen from D. F. Miss Brinson Conerly of the National Institute of Mental Health provided expert technical assistance in performing the analyses for urinary inorganic sulfate.

\section{REFERENCES}

1. Carson, N. A. J., D. C. Cusworth, C. E. Dent, C. M. B. Field, D. W. Neill, and R. G. Westall. 1963. Homocystinuria: a new inborn error of metabolism associated with mental deficiency. Arch. Dis. Childhood. 38: 425.

2. Gerritsen, T., and H. A. Waisman. 1964. Homocystinuria, an error in the metabolism of methionine. Pediatrics. 33: 413.

3. Cusworth, D. C., and C. E. Dent. 1969. Homocystinuria. Brit. Med. Bull. 25: 42.

4. Mudd, S. H., J. D. Finkelstein, F. Irreverre, and L. Laster. 1964. Homocystinuria: an enzymatic defect. Science (Washington). 143: 1443.

5. Laster, L., G. L. Spaeth, S. H. Mudd, and J. D. Finkelstein. 1965. Homocystinuria due to cystathionine synthetase deficiency. Ann. Intern. Med. 63: 1117.

6. Hollowell, J. G., Jr., M. E. Coryell, W. K. Hall, J. K. Findley, and T. G. Thevaos. 1968. Homocystinuria as affected by pyridoxine, folic acid, and vitamin $B_{12}$. Proc. Soc. Exp. Biol. Med. 129: 327.

7. Yoshida, T., K. Tada, Y. Yokoyama, and T. Arakawa. 1968. Homocystinuria of vitamin $B_{6}$ dependent type. Tohoku J. Exp. Med. 96: 235.

8. Gaull, G. E., D. K. Rassin, and J. A. Sturman. 1968. Pyridoxine-dependency in homocystinuria. Lancet. 2: 1302.

9. Gaull, G. E., D. K. Rassin, and J. A. Sturman. 1969. Enzymatic and metaoblic studies of homocystinuria effects of pyridoxine. Neuropädiatrie. 1: 199.

10. Mudd, S. H.; L. Laster, J. D. Finkelstein, and F. Irreverre. 1966. Studies on homocystinuria. In Symposium on Amine Metabolism in Schizophrenia. H. E. Himwich, J. R. Smythies, and S. S. Kety, editors. Pergamon Press, Inc., New York. 247.

11. Uhlendorf, B. W., and S. H. Mudd. 1968. Cystathionine synthase in tissue culture derived from human skin: enzyme defect in homocystinuria. Science (Washington). 160: 1007.

12. Barber, G. W., and G. L. Spaeth. 1967. Pyridoxine therapy in homocystinuria. Lancet. 1: 337.

13. Hooft, C., D. Carton, and W. Samyn. 1967. Pyridoxine treatment in homocystinuria. Lancet. 1: 1384.

14. Hambraeus, L., L. Wranne, and R. Lorentsson. 1968. Biochemical and therapeutic studies in two cases of homocystinuria. Clin. Sci. (London). 35: 457.

15. Carson, N. A. J., and I. J. Carré. 1969. Treatment of homocystinuria with pyridoxine: a preliminary study. Arch. Dis. Childhood. 44: 387.

16. Barber, G. W., and G. L. Spaeth. 1969. The successful treatment of homocystinuria with pyridoxine. J. Pediat. 75: 463.

17. Orr, M. L., and B. K. Watt. 1957. Amino acid content of foods. U. S. Dep. Agr. Home Econ. Res. Rep. No. 4. U. S. Government Printing Office, Washington, D. C.

18. Spackman, D. H., W. H. Stein, and S. Moore. 1958. Automatic recording apparatus for use in the chromatography of amino acids. Anal. Chem. 30: 1190 .

19. Crawhall, J. C., C. J. Thompson, and K. H. Bradley. 1966. Separation of cystine, penicillamine disulfide, and cysteine-penicillamine mixed disulfide by automatic amino acid analysis. Anal. Biochem. 14: 405.

20. Hawk, P. B., B. L. Oser, and W. H. Summerson. 1954. Practical Physiological Chemistry, 13th edition. Blakiston Division of the McGraw-Hill Book Company, Inc., New York. 949.

21. Meister, A. 1952. Enzymatic preparation of $\alpha$-keto acids. J. Biol. Chem. 197: 309.

22. Cavallini, D., and N. Frontali. 1954. Quantitative determination of keto-acids by paper partition chromatography. Biochim. Biophys. Acta. 13: 439.

23. Mudd, S. H., J. D. Finkelstein, F. Irreverre, and L. Laster. 1965. Transsulfuration in mammals: microassays and tissue distributions of three enzymes of the pathway. J. Biol. Chem. 240: 4382.

24. Laster, L., S. H. Mudd, J. D. Finkelstein, and F. Irreverre. 1965. Homocystinuria due to cystathionine synthase deficiency: the metabolism of $\mathrm{L}$-methionine. J. Clin. Invest. 44: 1708.

25. Bergel, F., and K. R. Harrap. 1961. Interaction between carbonyl groups and biologically essential substituents. III. The formation of a thiazolidine derivative in aqueous solution from pyridoxal phosphate and L-cysteine. J. Chem. Soc. (London). 4051. 
26. Buell, M. V., and R. E. Hansen. 1960. Reaction of pyridoxal-5-phosphate with aminothiols. J. Amer. Chem. Soc. 82: 6042.

27. Cavallini, D., N. Frontali, and G. Toshi. 1949. Ketoacid content of human blood and urine. Nature (London). 164: 792.

28. Mudd, S. H., F. Irreverre, and L. Laster. 1967. Sulfite oxidase deficiency in man: demonstration of the enzymatic defect. Science (Washington). 156: 1599.

29. Carey, M. C., J. J. Fennelly, and O., FitzGerald. 1968. Homocystinuria. II. Subnormal serum folate levels, increased folate clearance and effects of folic acid therapy. Amer. J. Med. 45: 26.

30. Kelly, S., and W. Copeland. 1968. A hypothesis on the homocystinuric's response to pyridoxine. Metab. (Clin. Exp.). 17: 794.

31. Roisin, M-P., and F. Chatagner. 1969. Purification et étude de quelques propriétés de l'homocystéine désulfhydrase du foie de rat. Identification a la cystathionase. Bull. Soc. Chim. Biol. 51: 481.
32. Brown, C., C. Brennan, and P. H. Gordon. 1968. Cystathionine synthase. Fed. Proc. 27: 782. (Abstr.)

33. Nakagawa, H., and H. Kimura. 1968. Purification and properties of cystathionine synthetase from rat liver: Separation of cystathionine synthetase from serine dehydratase. Biochem. Biophys. Res. Commun. 32: 208.

34. Kashiwamata, S., and D. M. Greenberg. 1969. Highly purified cystathionine synthetase of rat liver. Fed. Proc. 28: 668. (Abstr.)

35. Mudd, S. H. 1970. Errors of sulfur metabolism. In Symposium on Sulfur in Nutrition. O. H. Muth and J. E. Oldfield, editors. Avi Publishing Co., Westport, Conn. In press.

36. Greengard, O., and M. Gordon. 1963. The cofactormediated regulation of apoenzyme levels in animal tissues. I. The pyridoxine induced rise of rat liver tyrosine transaminase level in vivo. J. Biol. Chem. 238: 3708.

37. Holten, D., W. D. Wicks, and F. T. Kenney. 1967. Studies on the role of vitamin $B_{0}$ derivatives in regulating tyrosine $\alpha$-ketoglutarate transaminase activity in vitro and in vivo. J. Biol. Chem. 242: 1053. 